is increased, well-defined changes in the spectrum occur, and it may be possible to discover how the chlorine atoms are distributed along the long carbon chain. It is noteworthy that the spectra of polyvinyl chloride and polyvinylidene chloride differ from those of halothenes containing the same percentage of chlorine. Other compounds studied include polyvinyl alcohol, nylon, polyester waxes and novolac resins, and in each case structural features of value are obtained. Cellulose ethers and esters have also been examined, and in structural diagnosis the new method promises here to be an important supplement to X-ray work, while for practical purposes the identification and estimation of hydroxyl groups, aceto or butyro groups should be valuable.

Other general matters discussed by Thompson and Torkington included the differentiation of a polymer and its monomer, and the possibility of correlating spectrum with chain-length; and attention was also directed to the use of polarized infra-red radiation with oriented films of certain polymers.

Dr. Sutherland mentioned similar work on polymers carried out with Mr. Ramsay and Mr. Harding. Differences had been found between certain samples of polystyrene and of poly-isoprenes, and structural inferences had been made.

N. Sheppard and Dr. G. B. B. M. Sutherland described measurements on the spectrum of rubber after vulcanization and 'curing' by various reagents. The changes which occur during these processes can be followed by changes in the spectrum. Thus, if zinc oxide and stearic acid are used in the curing process, a band appears in the spectrum due to the stearate ion, which disappears again as the vulcanization proceeds. It is interesting also to find that, in the early stages of vulcanization at least, the band due to the carbon-carbon double bond in crepe rubber remains almost unchanged in intensity. The latter result was confirmed by Dr. Thompson in some similar studies in which rubber was treated with sulphur chloride vapour for different periods. In this case new bands were found in the spectrum which may be connected with sulphur-sulphur or carbon-sulphur linkages, and comparisons are required with the spectra of simple alkyl sulphides and disulphides.

Mr. C. G. Cannon discussed measurements on the infra-red spectrum of coal and coal extracts, and showed how various important groups may be identified in the samples. Although this work is so far exploratory in character, it indicates already that a new attack is possible on the differences between coals of varied origin.

Mr. H. A. Willis outlined similar measurements carried out with Dr. Sutherland on the infra-red spectrum of diamond, a subject investigated some years ago by Sir Robert Robertson and the late Sir John Fox. The new measurements suggest that another type of diamond has been found, and the authors stated that Sir C. V. Raman and his colleagues have recently misinterpreted Raman data. In the discussion, Sir Robert Robertson directed attention to the errors in measurement of the intensity of absorption bands which may be caused by scattering losses. Whatever the real explanation, it is clear that further measurements of this kind may lead to important knowledge about the different kinds of diamond.

The Faraday Society is to be congratulated on organizing this stimulating discussion.

1 J. Chem. Soc., 183 (1944).

\section{GORDON COLLEGE AT KHARTOUM \\ UNIVERSITY COLLEGE STATUS}

BY E. N. CORBYN

Former Principal of the College

A FORMAL inaugural opening of the reconstituted Gordon Memorial College at Khartoum will take place on February 20.

When in 1898 Lord Kitchener had won the battle of Omdurman, which opened the Sudan to civilization, and then went home to receive the thanks of his grateful fellow-countrymen, his first action was to ask for and receive from them by public subscription $£ 100,000$ for the building and endowment of a college at Khartoum in memory of General Gordon, for the education of the Sudanese.

In 1902 his return from the South African war gave him the opportunity to open the fine buildings erected on the bank of the Blue Nile, not far from the Palace where Gordon died. Those whom he had left behind in the Sudan, General Sir Reginald Wingate, his successor as governor-general, his young brotherofficers of the Royal Engineers who had taken charge of the new country's public works, Mr. (later Sir) James Currie, whom Lord Cromer had chosen as the first director of education, all had laboured to carry out the beginnings of his intention. What was his ultimate purpose he placed on record at the opening ceremony, when he said : "All I hope and trust is that it may be round this centre that development of higher education in the Sudan may be focused for all time"

The site allotted for the Gordon College was one of the best on the Khartoum river-front, and by far the most extensive. It covers many acres and includes, besides space for the buildings, ten football grounds intersected by avenues of shady trees. Its eastern boundary lies close to the Blue Nile Bridge, and along the road and railway embankment that makes a wide circular sweep round to the railway station behind the city of Khartoum. The main building, with a central block and two wings, is a large and impressive structure, the design making use of wide and lofty verandas, suitable to provide shäde from the violence of the tropical sun. Inland from the playing-fields are large boarding-houses, and the grounds contain also other educational buildings and staff houses.

Currie's task, as the first director of education in the Sudan, was to inspire with the breath of life the bricks and mortar which Kitchener had provided. This he had to do by bringing into the Sudan an adapted blend of Western and Arab education. $\mathrm{He}$ had seen the blend as approved in Egypt during a short period of service under Dr. Douglas Dunlop in the Egyptian Ministry of Education, which had enabled him to form his own ideas. In the tabula rasa of the Sudan, where he arrived in 1900, his opportunity was unique, and nobly he took it.

It was Currie's view that, at all events in the early formative years, the director of education should be also the principal of the Gordon College. He held that thus the College could best be integrated with the general educational machinery of the country, which also he was devising and installing, so he was insistent on presiding over both.

Even when, in its beginnings, to the ordinary man the College seemed to consist of a few Sudanese boys 
being taught by (at first) Egyptian teachers to become the future teachers of their fellow-countrymen (for so, of course, it had to start), Currie, with the eye of faith and imagination, saw it already as in part a university. He held that, if one side of his duties was to commence imparting instruction at the lowest level, another side was to have in the same buildings working examples of human knowledge at its highest level. So he gathered into his College all those branches of scientific research so necessary in a new land, but which, to be successful, must work in a congenial home. The new Government needed medical research, chemical research, entomological research, geological research. Currie opened to all of
Carter, was in process of establishing. These were to deal with matters of the personal law of the Sudanese (marriage, divorce, inheritance, etc.), who in the Arabic-speaking parts of the country are almost universally Mohammedans. Soon learned Sheikhs from the ancient University of El Azhar in Cairo were teaching promising classes in the study of their own religious law. The religious law courts of the Sudan have thus come now to be presided over by Sudanese 'Kadis', or judges.

At the lower levels the College housed at first what had to begin as education of the primary school stage. This developed into secondary school education, with vocational courses in the latter stages for

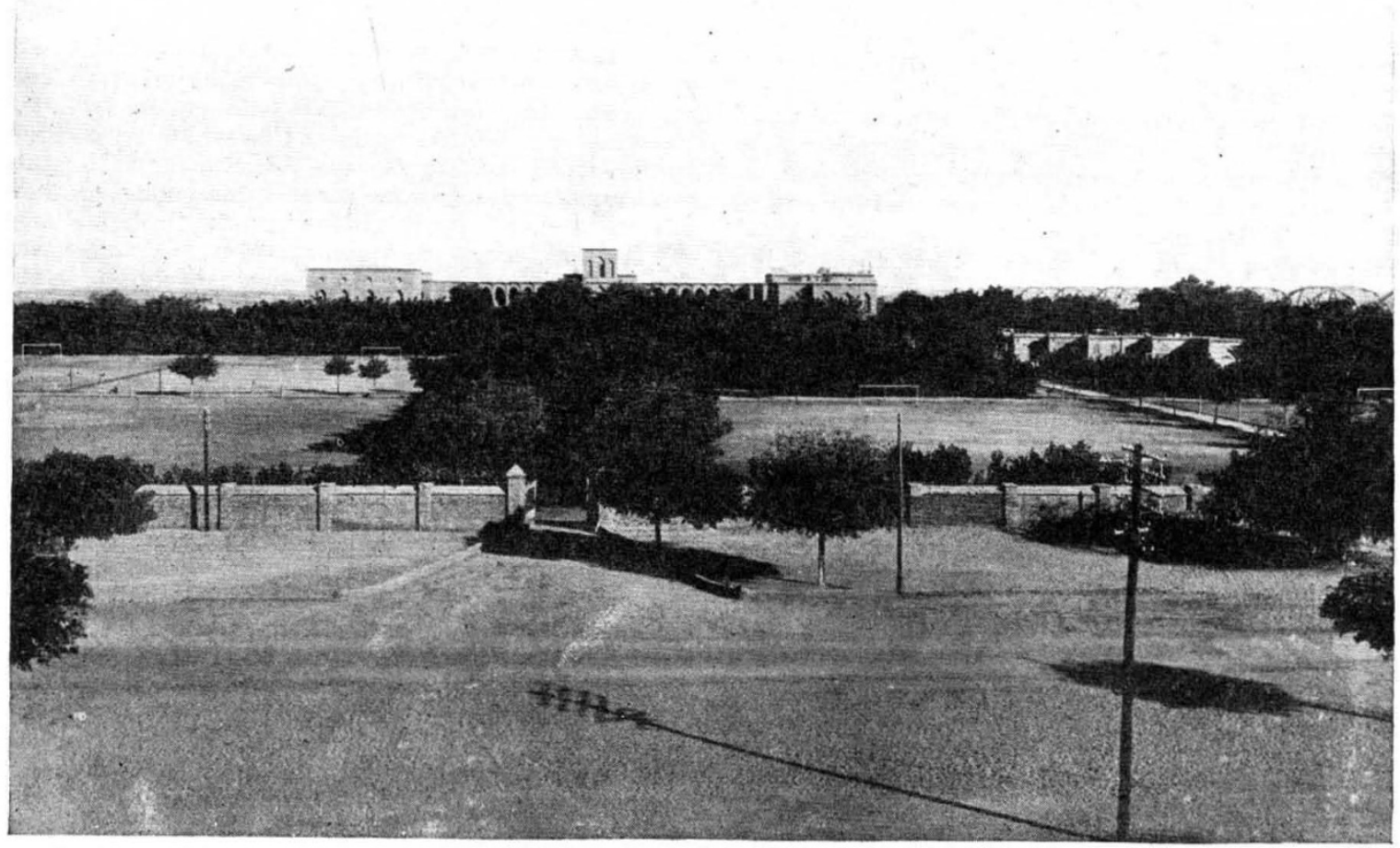

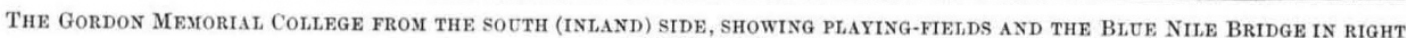
BACKGROUND.

them his arms and his buildings. He grouped them under him as principal of an institution in which research of highest university standard could work and flourish. This was only not a university because its brilliant staffs were there to do their own work on the problems of the country, and not, at that stage, to teach or give diplomas or degrees.

Such was Currie's conception. It was not always understood, even by fellow-workers in different spheres of the Sudan's administration. But what mattered was that he had brought it to birth and it existed, and it made the Gordon memorial buildings on the Blue Nile a centre of light and learning from the very start of the great enterprise for which they had been designed.

Meanwhile the early stages of education for the Sudanese went steadily forward. Currie was quick to seize on one indigenous branch as already of university standard-the study of Mohammedan law for the staffing of the Mohammedan law courts which the first Legal Secretary, Mr. (later Sir) Edgar Bonham engineers, teachers, and clerical Government staff. When the numbers in the secondary school grew so as to fill the buildings, the primary school was extruded and became the Khartoum primary school, housed elsewhere. Similarly, other primary schools were established in the other larger towns of the country, and became feeders for the secondary school in the Gordon College. This was often spoken of as though it alone was the Gordon College; but, as will have been seen from the details given above, the College was much more.

Such was Currie's Gordon College when he retired in 1914, and in essence it remained the same under his immediate successors. I was myself the third principal and director of education during 1926-27. My own suggestion for the next stage was to extrude the junior two years of the secondary school, by developing the four-year-course primary schools which fed it into six-year-course intermediate schools, and then to add two more senior years to the secondary school course, thus taking it two years further on 
into higher education. Changes remained in abeyance, however, until the whole Sudanese system of education was considered and reported on in 1937 by the De La Warr Commission. This Commission went further and recommended the extrusion of the whole four years of the secondary school course, and the transfer of the secondary school or schools elsewhere; so that the way might be clear at the Gordon College for the establishment of education at a postsecondary, or university college, stage.

Such was the programme which Mr. Christopher Cox, the sixth principal, taking up the De La Warr Commission's recommendations with admirable zeal and skill, was able to lay before the Sudan Government. In spite of the impact of the War on the country's finances, the Government decided to carry it out. The design included two (at first) secondary schools, placed in different parts of the country outside Khartoum, to which the secondary school in the Gordon College would be transferred. The buildings for the first of these, at Wadi Seidna on the Nile north of Khartoum, were just being completed as the War began. These buildings and the buildings of the Gordon College itself had then to be requisitioned for military purposes. The secondary school, instead of going to Wadi Seidna, had to find temporary accommodation opposite Khartoum in the big native eity of Omdurman, where it still remains until Wadi Seidna is free for its occupation.

The Gordon College buildings were released in 1944, thus removing the structural bar on the constitution of the new University College, the plans for which now took final shape. The early vocational courses had been developed into schools for education at a professional level. It was the grouping of these schools that was designed to constitute the University College.

In November 1944 there took place at Khartoum the first formal meetings of a Council set up to administer the College in that capacity. This Council becomes the authorized delegate for that purpose of the Executive Committee of the Gordon Mernorial College in London, under powers given to that Committee by the trust deed made when Lord Kitchener collected the endowment.

Included in the new College are six post-secondary schools - the School of Arts (which includes a School of Law), the School of Science, the School of Engineering, the School of Agriculture, the Khartoum Veterinary School, and the School of Administration and Police. This new united body of post-secondary schools now takes over the name, the buildings and the endowments of the Gordon Memorial College.

The reconstituted College will still leave outside its present framework two Sudanese educational institutions of post-secondary rank, the Kitchener School of Medicine at Khartoum, and the Institute of Education at Bakht er Ruda, which is in a rural setting on the White Nile about 120 miles south of Khartoum. The Kitchener School of Medicine, founded in 1924, though linked also with the Executive Committee of the Gordon Memorial College in London, has endowments subscribed in the Sudan and a constitution of its own. In addition to the income of its own endowments, it receives an annual subvention of a thousand guineas from the Lord Kitchener National Memorial Fund in London. The Institute of Education is established and administered by the Sudan Education Department. Both will be brought into organic relationship with the new University College in due course.
The College now, as a university college, will have a principal of its own, other than the director of education, and Dr. J. D. Tothill, recently director of agriculture and forests in the Sudan, has been nominated as the first holder of that post. The constitution devised for the College on university lines gives to its Council a large measure of independence from the Sudan Government. It is the Government's desire and purpose to grant to it, as soon as the money can be made available, ample endowments of its own, for which a figure of $£ 3,000,000$ is aimed at.

It remains to give some brief account of the details of the Schools of the College, which branch respectively from the School of Science and the School of Arts.

The School of Science has preparatory courses for the Kitchener School of Medicine, the Veterinary School, the School of Agriculture, the School of Engineering, and for teachers of science going to the Institute of Education. In 1945 it will commence also a three-year diploma course of its own.

The School of Medicine has a six-year diploma course, the School of Engineering a four-year one, and the Veterinary School and the School of Agriculture grant their diplomas after three years.

The School of Arts has a four-year diploma course in law, and three-year diploma courses in history, English, Arabic and geography. A two-year course is the condition for entry to the arts teachers' section of the Institute of Education, or to the School of Administration and Police, or to certain government employments.

Members of the new Gordon College inherit the fine hostels and beautiful playing-fields established in the past. These fortunate young Sudanese will have at their disposal all that is necessary for the building up of healthy minds in healthy bodies. The educational history of the Sudan in the past forty-five years leaves little doubt that they will rise to their opportunities.

\section{THE PEATS OF NEW JERSEY}

$T$ WO recently published bulletins ${ }^{1}$ provide a broad picture of the peat bogs of New Jersey. If these are read in conjunction with other publications ${ }^{2}$, one is given a wide purview of American east-coast peat bogs from Maine to Florida. In these various bulletins there is in particular very detailed information about the maritime peats, both the salt marsh and the mangrove types. One is chiefly impressed, however, by the scale upon which this study of the New Jersey peats was carried out. The investigation was treated as an official Work Projects Administration project, and fifteen to twenty-five field-crews of five men each were engaged upon it in addition to office and labora. tory staff, so that the total number employed was at one period about 150 persons. There is still scope for investigations on this scale in the British Isles, and it is to be hoped that the end of the War may see similar projects in being. In particular, British peat bogs or salt marshes would be eminently suited to this type of treatment, and in view of the possible value or use of such land for agricultural purposes there would seem to be a strong case for Government support of any such research programme on a commensurate scale.

The first bulletin is introductory in nature, and provides a general survey of peat as a whole. The 